Amudalat Issa
Mohammed B Abdulkadir
Omotayo O Adesiyun
Bilkis Owolabi
Surajudeen O Bello
Ruqayat R Bakare

DOI:http://dx.doi.org/10.4314/njp.v48i1.2

Accepted: 22nd August 2020

Amudalat Issa ( $\mathbf{\square}$ )

Children Specialist Hospital, Ilorin, Nigeria

Email:

issahamdallah27@gmail.com

Mohammed B Abdulkadir

Omotayo O Adesiyun

Ruqayat R Bakare

Department of Paediatrics and Child Health, University of Ilorin Teaching Hospital / University of Ilorin, Nigeria.

Bilkis Owolabi

General Hospital, Ilorin, Nigeria.

Surajudeen O Bello

Dalhatu Araf Specialist Hospital, Lafia Nasarawa State.

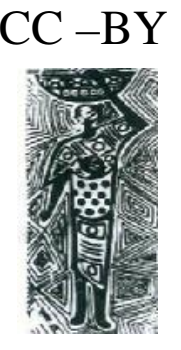

\title{
Serum brain natriuretic peptide in healthy Nigerian newborn babies
}

\begin{abstract}
Background: Brain natriuretic peptide (BNP) is a sensitive biomarker that is valuable in the management of childhood heart failure. Studies have reported racial differences in the level of BNP, especially in the adult population. The level of BNP in healthy Nigerian newborn babies is unknown. Hence, we determined the level of BNP in healthy term appropriate for gestational age (AGA) newborn babies.

Methods: This was a crosssectional study,85 healthy term AGA newborn babies aged 24 to 72 hours. The babies had relevant demographic parameters documented in a proforma and BNP assay analysed using ELISA method.
\end{abstract}

Results: The median IQR serum BNP level was 341.43 (313.39 to 425.45) pg/ml. The median level in females, was higher than males, \{393.86 (296.97- 460.62) pg/ml vs328.05 (313.61-389.39) pg/ml, $p$ $>0.05\}$.There was no significant relationship between serum BNP and birth weight, chronological age, gestational age, or mode of delivery ( $p>0.05$ in each case).

Conclusion: The study demonstrated high BNP levels in healthy term Nigerian newborns. There was no relationship between BNP, the chronological age, birth weight, gender, gestational age or mode of delivery in babies between 24 to 72 hours of life.

Keywords: Brain natriuretic peptide, term babies, healthy, Nigeria.

\section{Introduction}

Natriuretic peptides are ring-shaped amino acid sequences that serve important biochemical functions in animals. Three types have been described in humans namely A, B and C. ${ }^{1}$ Atrial natriuretic peptide (ANP) is synthesized and released from the right atrium. It has vasodilatory, diuretic and natriuretic properties. ${ }^{1}$ Brain natriuretic peptide (BNP) was first discovered in porcine brains. ${ }^{2}$ However, BNP has been found to be highly concentrated in the ventricles of the heart, hence, the current name B-type natriuretic peptide. C-type natriuretic peptide is found in the brain and coronary vessels. ${ }^{3}$

Brain natriuretic peptide is a 32 amino acid polypeptide containing a 17 amino acid ring structure common to all natriuretic peptides. ${ }^{2} \mathrm{BNP}$ is produced and released from the membrane granules of the myocardium in response to pressure and volume overload. ${ }^{4}$ Pro-BNP, the inactive precursor is cleaved into active BNP following the release from the myocardial granules. The inactive precursor has a half-life of 60 minutes while the active BNP has a half-life of about 20 minutes. ${ }^{4}$ These biomarkers peak in the first 3 to 4 days after birth and fall rapidly throughout the first month to low levels in childhood. ${ }^{5}$ BNP is known to cause diuresis, natriuresis, vasodilatation and antagonizes renin-angiotensin-aldosterone system leading to a reduction in intravascular volume, ven- tricular preload, and afterload. ${ }^{5}$ It is excreted largely by the kidneys, though endocytosis and lysosomal degradation also play a role. ${ }^{6}$ Other cardiac biomarkers in clinical practice are markers of necrosis (creatinine kinase, cardiac troponins, heart-type fatty acid binding protein); and inflammatory markers ( $\mathrm{C}$ reactive protein). The most reliable of these biomarkers are cardiac troponins and brain natriuretic peptide. ${ }^{7}$

Authors have documented distribution of BNP in healthy children ranging from first day of life up to 18 years. ${ }^{8,9,10}$ These studies demonstrated age to be a determinant of serum BNP level in healthy children. ${ }^{8,9,10}$ The studies demonstrated highest BNP in the first four days of life due to hemodynamic changes at birth. ${ }^{10}$ Most of the studies reported no relationship between serum BNP level and gender while a single study reported significantly higher level in female older than 10 years. Brain natriuretic peptide being a sensitive and reliable marker in the assessment and management of heart disease in children has gained popularity over the years. Despite its increasing popularity and relevance in clinical practice, a literature search revealed no published study on BNP levels among healthy African newborn babies. This study was therefore, designed to document BNP levels in healthy term Nigerian newborns. 


\section{Materials and Methods}

This descriptive cross-sectional study involving 85 newborn babies was conducted in the postnatal wards of the University of Ilorin Teaching Hospital between January and March 2017. Ethical clearance was obtained from the Hospital Ethics Review Committee. Written informed consent was obtained from parents after a clear explanation of the study objectives.

Inclusion criteria were term appropriate for gestational age (AGA) healthy newborns. The babies were recruited between 24 to 72 hours of life. Babies with clinical suspicion of congenital heart disease, major congenital anomalies, history of risk for sepsis, and clinical suspicion of sepsis were excluded. All the babies had their anthropometric parameters recorded and were classified based on gestational age using Lubchenco chart. ${ }^{11}$ Two millilitres of blood were collected from a convenient peripheral vein and transferred into a plain bottle. The blood sample was allowed to clot and fully retract for two hours at room temperature, then centrifuged at 1000 rpm for 15 minutes; serum was harvested and stored at $80^{\circ} \mathrm{C}$ in the Chemical Pathology laboratory.

The serum BNP was analyzed using human brain natriuretic peptide, BNP ELISA kit by Elabscience. The kit allows for in vitro quantitative determination of human BNP concentration in serum, plasma, and other body fluids. The ELISA kit uses the principle of competitive enzyme immunoassay and comes with a microplate well that is pre-coated with an antigen specific to human BNP (Elabscience manual). Analysis of BNP was done after samples had been collected from all subjects.

Data obtained was entered into a computer and analyzed using Statistical Package for Social Sciences (SPSS) software version 23.0 for Windows (SPSS Inc., Chicago, IL, USA). Mean and median were generated for continuous variables. Tests of relationship (MannWhitney U, Kruskal Wallis) and association (Spearman's correlation) were computed as appropriate. The results were presented using tables. A p value of less than 0.05 was considered statistically significant.

\section{Results}

Eighty-five healthy AGA newborn babies were recruited between 24 to 72 hours of life with mean \pm SD age of $31.47 \pm 17.13$ hours. The subjects comprised $44(51.8 \%)$ females, and $41(48.2 \%)$ males. The mean \pm SD gestational age was $39.12 \pm 1.45$ weeks (Table 1). Majority $(71.8 \%)$ of the babies were spontaneous vertex deliveries. The mean \pm SD birth weight was $3.08 \pm 0.32 \mathrm{Kg}$ as shown in Table 1

\begin{tabular}{lc}
\hline \multicolumn{2}{l}{ Table 1: General characteristics of the study population } \\
Variable & Mean $\pm \mathrm{SD}$ \\
\hline Age at sample collection (hours) & $31.5 \pm 17.1$ \\
Gestational Age (weeks) & $39.1 \pm 1.5$ \\
Birth weight (Kg) & $3.1 \pm 0.3$ \\
Occipitofrontal circumference (cm) & $34.5 \pm 1.5$ \\
Length (cm) & $48.8 \pm 2.7$ \\
Sex & $\mathrm{n}(\%)$ \\
Male & $44(51.8)$ \\
Female & $41(48.2)$ \\
Mode of delivery & \\
Spontaneous vertex & $61(71.8)$ \\
Emergency Caesarean section & $12(14.1)$ \\
Elective Caesarean section & $10(11.8)$ \\
Assisted vaginal & $2(2.4)$ \\
\hline
\end{tabular}

Figures in brackets are percentages of the study population

The median (IQR) serum BNP was 341.43 (313.39 to 425.45) $\mathrm{pg} / \mathrm{ml}$. The serum level in females, 393.86 (296.97-460.62) $\mathrm{pg} / \mathrm{ml}$, was higher compared to that of male subjects, 328.05 (313.61-389.39) $\mathrm{pg} / \mathrm{ml}$ but the difference was not significant, $\mathrm{p}=0.153$. Similarly, the levels were comparable across chronological age, gestational age groups, birth weight and delivery categories ( $p>0.05$ in each), Table 2.

\begin{tabular}{|c|c|c|c|}
\hline \multicolumn{4}{|c|}{$\begin{array}{l}\text { Table 2: Serum BNP levels across gender, gestational age and } \\
\text { postnatal age in the participants }\end{array}$} \\
\hline Variable & $\begin{array}{l}\text { Serum BNP } \\
\text { Median (IQR) }(\mathrm{pg} / \mathrm{ml})\end{array}$ & $\mathrm{U} / K$ & $p$ \\
\hline Sex & & & \\
\hline Male & $328.05(313.61-389.39)$ & 739.500 & 0.153 \\
\hline Female & $393.86(296.97-460.62)$ & & \\
\hline $\begin{array}{l}\text { Chronological age s } \\
24-<48 \text { hours }\end{array}$ & $339.49(311.64-418.24)$ & 432.000 & 0.283 \\
\hline $\begin{array}{l}48-72 \text { hours } \\
\text { Birth weight }(g)\end{array}$ & $389.39(322.47-604.61)$ & & \\
\hline $2500-3000$ & $341.43(313.61-422.16)$ & 887.50 & 0.912 \\
\hline $\begin{array}{l}3001-3999 \\
\text { Mode of delivery }\end{array}$ & $339.49(306.30-441.55)$ & & \\
\hline $\begin{array}{l}\text { SVD } \\
\text { CS }\end{array}$ & $\begin{array}{l}339.45(313.39-415.84) \\
369.36(315.84-500.90)\end{array}$ & 598.00 & 0.340 \\
\hline Gestational age gro & & & \\
\hline $\begin{array}{l}37-38 \text { weeks } \\
39-40 \text { weeks } \\
41-42 \text { weeks }\end{array}$ & $\begin{array}{l}335.63(296.97-414.06) \\
340.46(314.06-434.07) \\
397.84(314.45-503.34)\end{array}$ & 0.650 & 0.723 \\
\hline
\end{tabular}

Linear correlation showed no significant association between serum BNP and selected characteristics of the general population (age, gender, birth weight, gestational age and mode of delivery), $p>0.05$ in all, as shown in Table 3. 


\begin{tabular}{lll}
$\begin{array}{l}\text { Table 3: Correlation of serum BNP with general characteristic } \\
\text { of the population } \\
\text { Variables }\end{array}$ & \multicolumn{2}{l}{ Serum BNP } \\
& $R$ & $p$ \\
\hline Chronological age & 0.068 & 0.538 \\
Sex & 0.156 & 0.154 \\
Birthweight & 0.067 & 0.540 \\
Mode of delivery & -0.104 & 0.343 \\
Gestational age & 0.065 & 0.557 \\
\hline
\end{tabular}

\section{Discussion}

Brain natriuretic peptides is increasingly being deployed in diagnosis, monitoring and prognosticating heart disease in the paediatric population. ${ }^{10,12}$ Despite its increasing popularity and relevance in clinical practice, a literature search revealed no published study on BNP levels among healthy African new born babies.

The current study reported median (IQR) serum BNP levels of 341.43 (313.39 to 425.45$) \mathrm{pg} / \mathrm{ml}$ in healthy babies. This is higher than mean \pm SD of $231.60 \pm$ 197.50 to $278.98 \pm 190.47 \mathrm{pg} / \mathrm{ml}$ in previous studies among healthy Caucasian neonates. ${ }^{13,14}$ Differing statistical analysis methods may limit strict comparison as the current study reported median (IQR) while the earlier one reported mean $\pm \mathrm{SD}$ of serum BNP. It is also higher than median (IQR) of 242.00 (152.20 to 343.50$) \mathrm{pg} / \mathrm{ml}$ reported among healthy Italian neonates. ${ }^{15}$ The higher values herein reported may be attributable to racial differences. This is in keeping with earlier studies which demonstrated 1.5 fold higher values among Black adults in comparison with Caucasians. ${ }^{16}$

The lack of relationship between serum BNP, gender and gestational age in healthy term neonates is consistent with other studies. ${ }^{9,15}$. The finding of no association between serum BNP, gender, gestational age and birth weight and mode of delivery could not be compared because previous studies did not correlate serum BNP with these parameters.

Considering the difference between the serum BNP level in the current study compared with other studies and documented racial variation in adult population, ${ }^{16}$ it will be attractive to conduct a large population study among African neonates to confirm normal BNP levels in the neonates and compare with their Caucasian counterpart. The limitations in the current study include relatively small study population, narrow age range of recruitment, single rather than serial assay which limits comparison and generation of reference values.

\section{Conclusion}

The study demonstrated high BNP levels in healthy term Nigerian newborns compared with Caucasian counterpart in the first 24 hours to 72 hours of life. There was no relationship between the chronological age, birth weight, gender, gestational age and mode of delivery among the newborns in the first 24 to 72 hours of life.

Acknowledgement

We acknowledged the support of the chemical pathologist (Dr Oladosu W) who assisted in the analysis of BNP.

\section{References}

1 Vesely DL. Atrial natriuretic peptides in pathophysiological diseases. Res 2001; 51: 647-58.

2 Sudoh T, Kangawa K, Minamino N, Matsuo H. 33 A new natriuretic peptide in porcine brain. Nature 1988; 332: 7881.

3 Singh G, Kuc RE, Maguire JJ, Fidock M, Davenport AP. Novel snake venom ligand dendroaspis natriuretic peptide is selective for natriuretic peptide receptor-A in human heart: Downregulation of natriuretic peptide receptor-A in heart failure. Circ Res 2006; 99: 183190.

4 Witthaut R. Science review: Natriuretic peptides in critical illness. Crit Care 2004; 8: 3429.
5 Neves AL, Henriques-Coelho T, Leite-Moreira A, Areias JC. The utility of brain natriuretic peptide in pediatric cardiology: A review. Pediatr Crit Care Med 2016; 17: 529-38.

6 Linssen GCM, Damman K, Hillege HL, Navis G, Van Veldhuisen DJ, Voors AA. Urinary N-terminal prohormone brain natriuretic peptide excretion in patients with chronic heart failure. Circulation 2009; 120: 35-41.

7 Vasan RS. Biomarkers of cardiovascular disease: Molecular basis and practical considerations. Circulation 2006; 113: 2335-62.

8 Soldin SJ, Soldin OP, Boyajian AJ, Taskier MS. Pediatric brain natriuretic peptide and $\mathrm{N}$ terminal pro-brain natriuretic peptide reference intervals. Clin Chim Acta 2006; 366: 304 -8 .
9 Koch A, Singer H. Normal values of B type natriuretic peptide in infants, children, and adolescents. Heart 2003; 89: 875-8.

10 Law YM, Keller BB, Feingold BM, Boyle GJ. Usefulness of plasma B-type natriuretic peptide to identify ventricular dysfunction in pediatric and adult patients with congenital heart disease. Am J Cardiol 2005; 95: 474-8.

11 Lubchenco LO, Hansman C, Dressler M, Boyd E. Intrauterine growth as estimated. Pediatrics 1963; 32: 793-800.

12 Charpentier J, Luyt C-E, Fulla $\mathrm{Y}$, Vinsonneau C, Cariou A, Grabar S et al. Brain natriuretic peptide: A marker of myocardial dysfunction and prognosis during severe sepsis. Crit Care Med 2004; 32: 660-65. 
13 Stephanie B, Lynn L, Koch A, Falkenberg J, Mir TS. NT-ProB-type natriuretic peptide in infants and children : Reference values based on combined data from four Studies. Pediatr Cardiol 2009; 30: 3-8.

14 Simović A., Košutić JL, Prijić SM, Knežević JB, Vujić A., Stojanović N. The role of biochemical markers as early indicators of cardiac damage and prognostic parameters of perinatal asphyxia. Vojnosanit Pregl 2014; 71: 149-55.
15 Cantinotti M, Storti S, Parri S, Prontera C, Murzi B, Clerico A. Reference intervals for brain natriuretic peptide in healthy newborns and infants measured with an automated immunoassay platform. Clin Chem Lab Med 2010; 48: 697-700.
16 Krim SR, Vivo RP, Krim NR, Qian F, Cox M, Ventura $\mathrm{H}$ et al. Racial / ethnic differences in B-Type natriuretic peptide tevels and Their association with care and outcomes among patients hospitalized with heart failure findings from get with the guidelines heart failure. JACC 2013; 1 : 345-52. 